\title{
Multiregional, Not Multiple Origins
}

\author{
MILFORD H. WOLPOFF, ${ }^{1 *}$ JOHN HAWKS,${ }^{2}$ AND RACHEL CASPARI ${ }^{1}$ \\ ${ }^{1}$ Paleoanthropology Laboratory, Department of Anthropology, University \\ of Michigan, Ann Arbor, MI 48109-1382 \\ ${ }^{2}$ Department of Anthropology, University of Utah, Salt Lake City, \\ UT 84112
}

KEY WORDS multiregional evolution; modern human origins; polygenism; parallel evolution; independent origins; simultaneous evolution; treeness

\begin{abstract}
Multiregional evolution is a model to account for the pattern of human evolution in the Pleistocene. The underlying hypothesis is that a worldwide network of genic exchanges, between evolving human populations that continually divide and reticulate, provides a frame of population interconnections that allows both species-wide evolutionary change and local distinctions and differentiation. "Multiregional" does not mean independent multiple origins, ancient divergence of modern populations, simultaneous appearance of adaptive characters in different regions, or parallel evolution. A valid understanding of multiregional evolution would go a long way toward reducing the modern human origins controversy. Am J Phys Anthropol 112: 129-136, 2000. ๑ 2000 Wiley-Liss, Inc.
\end{abstract}

The past decade has seen very significant fossil (Duarte et al., 1999; Li and Etler, 1992; Lü, 1990; Pope, 1992) and genetic (Awadalla et al., 1999; Bower, 1999; Harding et al., 1997; Harris and Hey, 1999; Hey, 1997; Loewe and Scherer, 1997; Relethford, 1998; Wise et al., 1997, 1998) discoveries that directly address the modern human origins debate. Many believe they should have resolved it. But the debate has not been resolved. Several ideas about why the modern human origins debate continues unabated have been proposed, ranging from the influence of strong feelings and exacerbating personal comments in books and newspapers, to the contention that the debate cannot be resolved because the hypotheses are not sufficiently contradictory or even are untestable (see Clark and Willermet, 1997; Howell, 1996; Smith and Harrold, 1997). We believe there is a much simpler explanation. For whatever reason, or reasons (and we suspect there are more than one), there has been a continued pattern of misinterpreting or incorrectly de- scribing multiregional evolution. These misinterpretations follow a theme, in which multiregional evolution is depicted as parallel or independent evolution (often involving simultaneous changes) in the different inhabited regions of the world, ${ }^{1}$ and then is rejected because such a scheme is unlikely. There have been attempts to correct this (Frayer et al., 1993; Relethford, 1995, 1999; Smith, 1997; Wolpoff and Caspari, 1997).

There are historical reasons for this particular misinterpretation (Wolpoff and Caspari, 1997). Here we do not discuss these but rather focus on the literature of the past

*Correspondence to: Milford H. Wolpoff, Paleoanthropology Laboratory, Department of Anthropology, University of Michigan, Ann Arbor, MI 48109-1382. E-mail: wolpoff@umich.edu

Received 6 July 1999; accepted 13 January 2000.

${ }^{1}$ One of the reviews of this paper notes that "if you propose, and then espouse, a hypothesis about modern human origins and call it the 'Multiregional Hypothesis,' it is probably likely that people will think . . . that your hypothesis involved 'modern humanness' having more than one origin." But apart from the fact that multiregional evolution is a hypothesis about the pattern of human evolution, and not specifically about modern human origins (if there is such an event; see Wolpoff and Caspari, 1996), "multiregional" refers to nothing more or less than "many places" and there is no reason to assume it means "many places 
few years. The papers we discuss reflect the consistent consequences of interpreting multiregional evolution to mean parallelism and the simultaneous evolution of modernity. More than any other source could, they demonstrate by example why it is that without a valid understanding of the multiregional model, it is not possible to examine its consequences, test it, or make progress toward resolving the modern human origins debate. We present several examples from genetics and paleoanthropology.

\section{INTERPRETATIONS OF MULTIREGIONAL EVOLUTION}

\section{Independent origin of Homo sapiens in China}

As part of their analysis of microsatellite relationships between contemporary Chinese populations, Chu et al. (1998) discussed the multiregional evolution hypothesis and stated that it is incorrect because "genetic evidence does not support an independent origin of Homo sapiens in China" (Chu et al., 1998, p. 11763). Multiregional evolution does not predict the "independent" evolution of modern humans in China, or anywhere else in the Old World. It evokes diffusion across a network of genic exchanges, a mechanism that is the opposite of independent evolution, to account for the shared pattern of evolution across the human range combined with the presence of some regional continuities in various areas. The multiregional hypothesis is that a network of genic exchanges, promoted by but not necessarily dependent on exogamy rules, ${ }^{2}$ provides a frame of population interconnections that allows both species-wide

\footnotetext{
where the same things happen at the same time independently of each other."

${ }^{2}$ Native Australian marriage preference is defined by descent group, they must marry outside their clan, but they are not required to marry outside their "tribe" (defined by dialect and territory, these are the smallest breeding populations on the continent according to Birdsell, 1958). Yet even without "tribal" exogamy rules, the data of Tindale (1940) on Native Australian marriages show that for each generation, on average $13 \%$ of marriages were with a neighboring "tribe" and $1.6 \%$ were with "tribes" whose borders were not adjoining (Lasker and Crews, 1996). Ignoring population movements and reticulations (which would speed up the process), this is more than sufficient to insure a much greater magnitude of genic exchange than the less than one migrant per generation between regional populations that the multiregional model requires to work (Relethford, 1999; Relethford and Harpending, 1995).
}

evolutionary change and local distinctions and differentiation. As the evolving human populations continued to diverge and reticulate, this network has had several consequences. It encouraged geographic differentiation through isolation-by-distance for neutral traits. For traits that were not neutral, it allowed advantageous features, promoted by selection, to spread everywhere throughout humanity. Traits such as these are widely shared, but differentiation in other adaptive traits across this network reflects adaptive variation, tempered by historic differences. ${ }^{3}$ Even when the distribution of the causes of adaptation are not clinal, there can be widespread gradations of variation maintained by gene flow balanced against selection differences or drift. Because of the key role played by genic exchanges in this model, multiregional evolution means that no human species, subspecies, or race can have multiple "independent origins" in different regions. If genetic loci have evolved in the absence of selection, as is often assumed for microsatellites such as those examined in Chu et al. (1998), then multiregional evolution predicts there will be a pattern of isolation-bydistance and expects reticulate evolution among populations.

However, Chu et al. (1998) provide no test of whether the Chinese microsatellite data fit an isolation-by-distance model, nor do they assess the effects of population reticulation on the observed population structure. Instead, they use a standard algorithm to fit their data to a branching model, or tree, of population relationships. Just as regression may be fit to any pair of metric variates, any matrix of population distances may be fit to a tree. However, as in the case of regression, we must evaluate a priori whether a tree is an appropriate model for the population relationships. In the case of these microsatel-

\footnotetext{
${ }^{3} \mathrm{~A}$ new source of selection can only modify what is already present (Gould and Vrba, 1982), barring the unlikely occurrence of a useful mutation at just that moment. Therefore, while population differences in adaptive features reflect adaptive variation, the details of the differences may, in some cases, be found in variation created by random genetic drift at an earlier time. The same difference in selection does not necessarily cause the same difference in the morphological response to it, so population history can be a key element in this process even before the process has begun.
} 
lite data, there are two obvious hypotheses to explain the observed interpopulational distances. First, we may believe that a series of population divergences, perhaps accompanied by founder events, led to the differences. If this were true, a tree would be the appropriate model to fit to the data. Second, we may believe that differences in migration among the populations led to the differences, in which case a tree would be clearly inappropriate. Either of these two hypotheses will result in a matrix of population differences, and the observation of such a matrix is not sufficient to determine which hypothesis is the correct one (Relethford, 1995). They may be distinguished, however, by testing the goodness of fit of the data to a tree model, measuring the "treeness" ${ }^{4}$ of the data. In this case, Chu et al.(1998) do not report the treeness of the microsatellite data. This is an important omission, both because analysis of diverse human genetic data demonstrates that treeness can be rejected for global samples of living human groups (Templeton, 1998), and because a high treeness is the only way that distance data could refute an isolationby-distance model for humans in China.

The further conclusion that "modern humans originating in Africa constitute the majority of the current gene pool in East Asia" (Chu et al., 1998, p. 11766) is also compatible with the multiregional hypothesis, given the stipulation, common to most modern human origins explanations, that until recently more people lived in Africa than in other parts of the world (Relethford, 1999). In this respect, multiregional evolution and uniregional replacement have similar expectations, since Africa makes up half or more of the inhabited land mass of the world prior to 100,000 years ago. In contrast, multiregional evolution can easily be disproved if it can be shown that all of the ancestors of living humans at some discrete time in the Middle or Late Pleistocene lived in only one area of the world. If this were the

\footnotetext{
4"Treeness" is exhibited when all of the endpoints on one side of a split are equally related to all of the endpoints on the other side. If there were migration and genic exchanges between groups at the endpoints, then the relations would depend on the pattern of migration and not on the split. In this case, equal relationships would not be found.
}

case, then we should be able to trace the ancestry of every human genetic locus to a single population existing at some time in the past million years. This testing is actively underway using genetic evidence, and no such time has yet been found at which every genetic locus resides in a single African population (Harris and Hey, 1999; Harding et al., 1997). However, such a test has not been performed on microsatellite data, and no such test is performed in this study.

\section{Unique descent}

The commentary accompanying Chu et al. (1998) emphasized the inference that the majority of East Asian genes came from Africa, and concluded, "This should help refute the claim that there is a continuity of evolution from Homo erectus to modern humans in East Asia, as maintained by supporters of the multiregional hypothesis" (Cavalli-Sforza, 1998, p. 11502). This is a misrepresentation of the term "continuity" as explicitly employed in the multiregional model, by confusing the continuity of features with a claim of unique descent, ${ }^{5}$ and as noted above, most modern human origins explanations agree about where the majority of Pleistocene humans lived.

\section{The Neandertal lynchpin}

It is further stated (Cavalli-Sforza, 1998, p. 11502) that "another stronghold of the multiregional hypothesis was the transformation of Neanderthal into modern humans in Europe, and also this has been falsified by an analysis of DNA of the Neanderthal par excellence." Europe (especially Western Europe) and the fate of the Neandertals have never been a "stronghold" of the multiregional evolution hypothesis, which was

\footnotetext{
${ }^{5} \mathrm{~A}$ claim of unique descent from ancient to modern Asian populations would not be multiregional evolution, but polygenic evolution. Regional continuity refers to the observation that very common features persist in different regions for long periods of time. It is not the claim that such features do not appear elsewhere; the genetic structure of the human species makes such a possibility unlikely to the extreme. There may be uniqueness in combinations of traits, but no single trait is likely to have been unique in a particular part of the world, although it might appear to be so because of the incomplete sampling provided by the spotty human fossil record. Neither is it the claim that such features persist for the entire period of habitation of a region, for such a claim would disregard population replacements and extinctions, as well as the action of natural selection for some features, all of which are usual evolutionary events.
} 
explicitly developed to account for the fossil evidence in East Asia (Wolpoff et al., 1984).

The interpretation by Cavalli-Sforza (1998) is based on the assumption that the Neandertal's distinct mtDNA lineage is a separate biological lineage, reflecting a population (or paleodeme) that diverged from humanity when the mtDNA lineage branched, and subsequently evolved in parallel with humans. But mtDNA lineages are not separate populations, and population genetics demonstrates that the reported $\mathrm{Ne}$ andertal mtDNA cannot falsify any relevant evolutionary model for European origins (Nordborg, 1998; Wolpoff, 1998). To date, there is only one published partial sequence of Neandertal mtDNA, and it has not been compared with the mtDNA of its contemporaries, but instead only with that of living humans. The problem is, as Nordborg (1998) lays out, that only a very few ancestors of the world sample of human mtDNA were present in contemporaries of the Feldhofer Neandertal. This means that the total sample of mtDNA that could be compared is very small. At the moment, the analysis that has been done has demonstrated little more than what has been accepted paleontologically for over 100 years: Neandertals were biologically at the fringes of the range of variation of living humanity. No Neandertals can be found today, although most of their features remain, at differing frequencies (Frayer, 1992). Moreover, and perhaps most relevantly, multiregionalism could be a valid explanation for human evolution even if every Neandertal became extinct without issue. No human populations persist endlessly or continuously through time; all either become extinct, or merge with other populations.

\section{An extreme theory of multiple origins}

In another paper, multiregional evolution was portrayed as an "extreme version of the origin of modern humans (Homo sapiens sapiens) from Homo erectus . . . [with] multiple origins, one in almost every continent" (Li et al., 1999, p. 3796). There is a serious question about whether modernity can be defined in a way that would allow a statement like this to be valid (Wolpoff and Caspari, 1997), and no multiregionalist has proposed a subspecies taxonomy for modern humans, but even more serious, and disturbing, is the persistent contention that multiregionalism means multiple origins. The fundamental difference between multiregional evolution and all replacement theories is that multiregional evolution describes a process within a single evolving species and therefore is a reticulate model in which there is branching, extinction, and merging of populations. In contrast, replacement theories, such as the single recent African origin of modern humans, describe a process of evolution by branching alone, in which reticulations are impossible. The branching process is assumed a priori and is the basis of analyses to account for both the origin of modern humans and the differentiation of these humans into the different, widespread populations found today.

It is correct to say that multiregional evolution and evolution by replacement are extremes, because there is no process that can lie between them or be a compromise. But authors who continue to regard the multiregional hypothesis as a "candelabra theory" (Lewin, 1993; Seielstad et al., 1999) are simply incorrect. Ironically, it is the branching replacement model that must be described as a "candelabra" (Templeton, 1998), because branching is the only explanation this theory offers for variation. In the replacementist view, morphological variation in the Middle and Late Pleistocene is the result of branching of different species, and genetic variation among living humans is the result of the branching of ancestral human populations. By assuming population variation to be a reflection of the time since common ancestry of diverging populations, replacementists are forced to accept parallel evolution to explain Middle and Late Pleistocene changes across the human range, and complete population isolation to explain the observed worldwide pattern of genetic diversity in living humans.

\section{Parallel independent evolution}

The depiction of multiregional evolution as a polygenic theory of multiple origins and parallel evolution continues in paleontology as well as in human genetics. In the most recent paper by the two paleoanthropolo- 
gists who disagree with multiregional evolution most strongly, we find the comment, "Frayer (1992) also proposes, on the basis of the persistence of traits across the Neandertal/modern boundary, a degree of continuity indicating 'some measure of genetic contribution of Neandertal to subsequent Homo sapiens populations' . . this view no longer means regional evolution" (Bräuer and Stringer, 1997, p. 199). But given the reticulate nature of evolution within species, and the ethnogenic modeling that is part of the multiregional framework (Moore, 1994), what else could regional evolution mean unless multiregional evolution is still being interpreted by these scholars as parallel independent evolution in different regions? Elsewhere, Stringer and McKie (1996, p. 141) assert that "multiregionalism . . . holds that our brain development is an event of all-consuming global consequence towards which humanity strived in unison for nearly two million years. ... to believe that humanity could be the product of a small, rapidly evolving African population who struck it lucky in the evolution stakes is therefore viewed as being worse than apostasy by these people." Gould (1994) writes, "Multiregionalism is awfully hard to fathom. Why should populations throughout the world, presumably living in different environments, under varying regimes of natural selection, all be moving on the same evolutionary pathway?" Howell (1996, p. 32) asserts, "MRE requires that natural selection drive African and African-derived hominin populations in Eurasia anagenetically and ineluctably toward the modern human condition. It has an almost omega-point inevitability about it."

\section{Simultaneous appearance of modernity as mutations accumulate because of relaxed selection}

Natural selection is not the only force "posited" to drive simultaneous parallel evolution in these innovative depictions of multiregional evolution; there is also the $a b$ sence of natural selection. Smith and Harrold (1997), writers who do not particularly support the Eve theory, provide an example which mistakes multiregional evolution for parallelism and uses the absence of selection to account for it. The model they describe as multiregional evolution is actually that of Brace (1991), i.e., "stages of human evolution." ${ }^{6}$ Brace (1991, p. 52) asserts that multiregional evolution is, in actuality, no more than his PME (probable mutation effect), when he contends, "The idea of the emergence of modern human form gradually and simultaneously throughout the entire occupied world or 'in situ continuity' has recently been rechristened 'multiregional evolution."'7 According to Brace (1991), his worldwide evolutionary stages are based on a theory of parallel evolution that evokes human culture as the common source of parallel trends that cause simultaneous changes, and the accumulation of mutations in the absence of selection ${ }^{8}$ as the mechanism that creates the parallelisms (culture removes selection, in Brace's view).

Simply put, Smith and Harrold (1997) turn to this cultural explanation for common parallel evolutionary trends in human populations because they do not believe there is enough gene flow for the multiregional model to work without it. They reject the interpretation of Templeton (1993) of mtDNA distribution as reflecting a long history of "restricted gene flow among Old World human populations with no single source population for all genetic variation." Instead, they cite Livingstone (1992), whose simple simulations "showed" that genes cannot move fast enough, Stringer and McKie (1996), who assert that the level of gene flow that multiregional evolution requires is "improbable," and Howell (1994, p. 304) who commented that the multiregional mechanism "stretches the bounds of credulity ... there is serious need for normal procedures of evolutionary biology to prevail." This is all wrong. Several evolutionary biologists have calculated the magnitude of gene flow required for multiregional evolution to work, and it is very low. Estimates of

\footnotetext{
${ }^{6}$ Although Brace's "stages of human evolution" is very different from multiregional evolution, he treats it as an only slightly modified version, and Smith and Harrold (1997) accept this.

${ }^{7}$ This, of course, is not true; it is neither a valid description of multiregional evolution, nor an accurate portrayal of its intellectual roots (see Wolpoff and Caspari, 1997).

${ }^{8}$ However, this "probable mutation effect" is not regarded as a valid evolutionary mechanism (Calcagno and Gibson, 1988).
} 
the number of people who need move between continents each generation for isolation by distance to explain the existing multiregional distribution of neutral genes average only a few each generation (Harpending et al., 1996; Relethford, 1998; Templeton, 1998). In fact, Relethford (1999) shows that on average, less than one migrant per generation is sufficient, hardly a large enough number to justify the comment that multiregional evolution must require an unacceptably large amount of migration in order to work. The estimate of Relethford (1999) is a maximum because it is for neutral genes. Genes under selection may have spread with much less migration, since their ultimate frequency and pattern of dispersion are controlled by the magnitude of selection, which in large populations is greater than the effect of migration on frequencies. Smith and Harrold (1997) accept the formulation of Brace (1991), in which culture relaxes selection and thereby creates parallel changes as structures reduce because of mutations, as being the multiregional model. It is not, and it is not necessary to accept so improbable an explanation as the probable mutation effect to account for the worldwide evolution of the human species.

\section{DISCUSSION}

"Multiregional" does not mean independent multiple origins, ancient divergence of modern populations, simultaneous appearance of adaptive characters in different regions, or parallel evolution. By depending on genic exchanges as the basis of its explanation of how differentiation, geographic variation, and evolutionary change within the human species take place, multiregional evolution is the antithesis of these. Therefore, the incorrect portrayals and invalid assumptions about the basis of multiregional evolution challenge our valid understanding of the issues, and undermine attempts to make progress in resolving them. One might gather from this essay that we contend that most authors who believe multiregional evolution is invalid, are in fact mistaking multiregional evolution for multiple origins. To a great extent this is correct. But it is not at all universally true.
Prominent paleoanthropologists such as Tattersall (1997) and population geneticists such as Harpending et al. (1998) are truly exceptions to this generalization. They describe multiregional evolution correctly, but do not believe it is valid. There may be others who understand the model and yet disagree with it, but there are not many, and certainly not enough to suggest that misunderstanding multiregional evolution and the conviction it is wrong are unrelated.

Of course, the controversy does not persist solely because multiregional evolution is improperly understood, although misunderstandings have played an important role in how the controversy developed and their continuation has helped this controversy endure. Lying beneath this is a disagreement that mainly persists, and will continue to persist, because explanations of modern human origins through the mechanisms of complete replacement and worldwide evolution of a single species fully contradict each other. One of them must be wrong, and either is a valid refutation of the other. There is no compromise position to make it easier to find a synthesis of the views or form the basis of a consensus that might make some more comfortable. Instead, we would predict that the posturing, spin-doctoring of new data, and repositioning will continue until one side admits it is mistaken, or more likely, turns its attentions to other problems and, like the Ramapithecus debate, this one fades away. But we believe this can never happen until accuracy is achieved in portraying the evolutionary explanation that some authors are so sure is incorrect.

\section{LITERATURE CITED}

Awadalla P, Eyre-Walker A, Smith jm. 1999. Linkage disequilibrium and recombination in hominid mitochondrial DNA. Science 286:2524-2525.

Birdsell JB. 1958 On population structure in generalized hunting and collecting populations. Evolution 12:189-205.

Bower B. 1999. DNA's evolutionary dilemma: genetic studies collide with the mystery of human evolution. Sci News 155:88.

Brace CL. 1991. Cultural innovation and the mechanism for the emergence of modern morphology [abstract]. Am J Phys Anthropol [Suppl] 12:52.

Brace CL. 1995. Biocultural interaction and the mechanism of mosaic evolution. Am Anthropol 97:711-721.

Bräuer G, Stringer C. 1997. Models, polarization, and perspectives on modern human origins. In: Clark GA, Willermet CM, editors. Conceptual issues in modern 
human origins research. New York: Aldine de Gruyter. p 191-201, 437-492.

Calcagno JM, Gibson KR. 1988. Human dental reduction: natural selection or the probable mutation effect. Am J Phys Anthropol 77:505-517.

Cavalli-Sforza LL. 1998. The Chinese human genome diversity project. Proc Natl Acad Sci USA 95:1150111503.

Cavalli-Sforza LL, Menozzi P, Piazza A. 1993. Demic expansions and human evolution. Science 259:639646.

Chu JY, Huang W, Kuang SQ, Wang JM, Xu JJ, Chu ZT, Yang ZQ, Lin KQ, Li P, Wu M, Geng ZC, Tan CC, Du RF, Jin L. 1998. Genetic relationship of populations in China. Proc Natl Acad Sci USA 95:117631178.

Clark GA. 1997. Through a glass darkly: conceptual issues in modern human origins research. In: Clark GA, Willermet CM, editors. Conceptual issues in modern human origins research. New York: Aldine de Gruyter. p 60-76, 437-492.

Clark GA, Willermet CM. 1997. Introduction to conceptual issues in modern human origins research. In: Clark GA, Willermet CM, editors. Conceptual issues in modern human origins research. New York: Aldine de Gruyter. p 1-8, 437-492.

Duarte C, Maurício J, Pettitt PB, Souto P, Trinkaus E, van der Plicht H, Zilhão J. 1999. The early Upper Paleolithic human skeleton from the Abrigo do Lagar Velho (Portugal) and modern human emergence in Iberia. Proc Natl Acad Sci USA 96:7604-7609.

Frayer DW. 1992. The persistence of Neandertal features in post-Neandertal Europeans. In: Bräuer G, Smith FH, editors. Continuity or replacement? Controversies in Homo sapiens evolution. Rotterdam: Balkema. p 179-188.

Frayer DW, Wolpoff MH, Smith FH, Thorne AG, Pope GG. 1993. The fossil evidence for modern human origins. Am Anthropol 95:14-50.

Gould SJ. 1994. So near and yet so far. NY Rev Books 24-28.

Gould SL, Vrba E. 1982. Exaptation-a missing term in the science of form. Paleobiology 8:4-15.

Harding RM, Fullerton SM, Griffiths RC, Bond J, Cox MJ, Schneider JA, Moulin DS, Clegg JB. 1997. Archaic African and Asian lineages in the genetic ancestry of modern humans. Am J Hum Genet 60:722789.

Harpending S, Batzer MA, Gurven M, Jorde LB, Rogers AR, Sherry ST. 1998. Genetic traces of ancient demography. Proc Natl Acad Sci USA 95:1961-1967.

Harpending HC, Relethford JH, Sherry ST. 1996. Methods and models for understanding human diversity. In: Boyce AJ, Mascie-Taylor CGN, editors. Molecular biology and human diversity. Cambridge: Cambridge University Press. p 283-299.

Harris EE, Hey J. 1999. X chromosome evidence for ancient human histories. Proc Natl Acad Sci USA 96:3320-3324.

Hey J. 1997. Mitochondrial and nuclear genes present conflicting portraits of human origins. Mol Biol Evol 14:166-172.

Howell FC. 1994. A chronostratigraphic and taxonomic framework of the origins of modern humans. In: Nitecki MH, Nitecki DV, editors. Origins of anatomically modern humans. New York: Plenum Press. p 253-319.

Howell FC. 1996. Thoughts on the study and interpretation of the human fossil record. In: Meikle WE, Howell FC, Jablonski NG, editors. Contemporary issues in human evolution. Wattis symposium series in anthropology, California Academy of Sciences memoir. Volume 21. p 1-45.

Lasker GW, Crews CE. 1996. Behavioral influences on the evolution of human genetic diversity. Mol Biol Evol 5:232-240.

Lewin R. 1993. The origin of modern humans. New York: Scientific American Library.

Li J, Underhill PA, Doctor V, Davis RW, Peidong S, Cavalli-Sforza LL, Oefner PJ. 1999. Distribution of haplotypes from a chromosome 21 region distinguishes multiple prehistoric human migrations. Proc Natl Acad Sci USA 96:3796-3800.

Li T, Etler DA. 1992. New Middle Pleistocene hominid crania from Yunxian in China. Nature 357:404-407.

Livingstone FB. 1992. Gene flow in the Pleistocene. Hum Biol 64:67-80.

Loewe L, Scherer S. 1997. Mitochondrial Eve: the plot thickens. Tree 12:422-423.

Lü Z. 1990. La découverte de l'homme fossile de Jingniu-shan. Prem Etud Anthropol 94:899-902.

Moore JH. 1994. Putting anthropology back together again: the ethnogenetic critique of cladistic theory. Am Anthropol 96:925-948.

Nordborg M. 1998. On the probability of Neanderthal ancestry. Am J Hum Genet 63:1237-1240.

Pope GG. 1992. Craniofacial evidence for the origin of modern humans in China. Yrbk Phys Anthropol 35: $243-298$.

Relethford JH. 1995. Genetics and modern human origins. Evol Anthropol 4:53-63.

Relethford JH. 1998. Genetics of modern human origins and diversity. Annu Rev Anthropol 27:1-23.

Relethford JH. 1999. Models, predictions, and the fossil record of modern human origins. Evol Anthropol 8:710

Relethford JH, Harpending HC. 1995. Ancient differences in population size can mimic a recent African origin of modern humans. Curr Anthropol 36:667674 .

Seielstad M, Bekele E, Ibrahim M, Touré A, Traoré M. 1999. A view of modern human origins from Y chromosome microsatellite variation. Gene Res 9:558567.

Smith FH. 1997. Modern human origins. In: Spencer F, editor. History of physical anthropology. An encyclopedia. New York: Garland Publishing Inc. p 661-672.

Smith SL, Harrold FB. 1997. A paradigm's worth of difference? Understanding the impasse over modern human origins. Yrbk Phys Anthropol 40:113-138.

Stringer CB, McKie R. 1996. African exodus: the origins of modern humanity. London: Jonathan Cape.

Tattersall I. 1997. Out of Africa again . . . and again? Sci. Am 276:60-67.

Templeton AR. 1993. The "Eve" hypotheses: a genetic critique and reanalysis. Am Anthropol 95:51-72.

Templeton AR. 1998. Human races: a genetic and evolutionary perspective. Am Anthropol $100: 632-650$.

Tindale NB. 1940. Distribution of Australian Aboriginal tribes: a field survey. Trans R Soc S. Austr 64:140231.

Willermet CM, Hill B. 1997. Fuzzy set theory and its implications for species models. In: Clark GA, Willermet CM, editors. Conceptual issues in modern human origins research. New York: Aldine de Gruyter. p 77-88, 437-492.

Wise CA, Sraml M, Easteal S. 1998. Departure from neutrality at the mitochondrial NADH dehydrogenase subunit 2 gene in humans, but not in chimpanzees. Genetics 148:409-421.

Wise CA, Sraml M, Rubinsztein DC, Easteal S. 1997. Comparative nuclear and mitochondrial genome di- 
versity in humans and chimpanzees. Mol Biol Evol 14:707-716

Wolpoff MH. 1998. Concocting a divisive theory. Evol Anthropol 7:1-3.

Wolpoff MH, Caspari R. 1996. An unparalleled parallelism. Anthropologie (Brno) 34:215-223.

Wolpoff MH, Caspari R. 1997. Race and human evolution. New York: Simon and Schuster.

Wolpoff MH, Wu X, Thorne AG. 1984. Modern Homo sapiens origins: a general theory of hominid evolution involving the fossil evidence from east Asia. In: Smith FH, Spencer F, editors. The origins of modern humans: a world survey of the fossil evidence. New York: Alan R. Liss. p 411-483.

Wolpoff MH, Thorne AG, Smith FH, Frayer DW, Pope GG. 1994. Multiregional evolution: a world-wide source for modern human populations. In: Nitecki MH, Nitecki DV, editors. Origins of anatomically modern humans. New York: Plenum Press. p 175199. 